\title{
The Many Faces of Malaysian English
}

\author{
Jantmary Thirusanku and Melor Md. Yunus \\ Faculty of Education, National University of Malaysia, Selangor Darul Ehsan 43600, Bangi, Malaysia \\ Correspondence should be addressed to Jantmary Thirusanku, eambjs@gmail.com
}

Received 18 December 2011; Accepted 29 January 2012

Academic Editor: U. Moore

Copyright ( 12012 J. Thirusanku and M. Md. Yunus. This is an open access article distributed under the Creative Commons Attribution License, which permits unrestricted use, distribution, and reproduction in any medium, provided the original work is properly cited.

\begin{abstract}
This paper provides a brief description on the aspect of Malaysian English lexis. It starts off with the developmental cycles of new varieties of English based on three main models by three main scholars, namely, Kachru's three concentric circles of Englishes (1994), Moag's life-cycle model (1982), and Schneider's dynamic model (2007). It discusses the emergence and development of Malaysian English, the nonnative variety. It also explains Baskaran's three levels of the lectal continuum; acrolect, mesolect, and basilect. The nonnative features involved in the Malaysian English lexis are also discussed briefly; the acrolect: borrowing, the mesolect, and basilect mixing, with examples. Generally, it discusses the emergence of the new varieties, the indigenisation of English in Malaysia, and the current status of English in Malaysia.
\end{abstract}

\section{Introduction}

The English language has spread to many parts of the world. The increase in the number of those learning it and using it has been the most striking example of "language expansion" in this century [1]. It has become the most important international language and is the most commonly taught second or foreign language in the world. Recent facts from the Internet show that there are about 780 million users of English of whom about 380 million are native speakers, about 300 million are second language speakers, and about 100 million are foreign language speakers [2].

John Adams in Kachru [3] made a prediction about the English language that eventually came true. He said that English would be the most respectable language in the world and the most universally read and spoken in the century. This prediction was made in the 19th century and in this 21 st century, it has become a reality. Sources from the British Council suggest that English is used in over 70 countries as an official or semiofficial language, and by the year 2000 it was estimated that over one billion people were learning English. Why is English given so much importance in so many countries? According to Kachru [4], English is often learned because of its literary heritage and the status accorded to the reader or speaker. Furthermore, it opens doors to technology, science, trade, and diplomacy.
English as an international language is the most widespread medium of worldwide communication [5]. According to Smith [6], it is the principal language of international politics, commerce, technology, and aid as well as the language of science and technology. Smith further claims that as an international language, it is not bound to any one culture, and priority is given to communication. There is also no need for nonnative users of English to sound like the native speaker, but simply to use language, which is "appropriate, acceptable and intelligible" [6]. Thus, English is learnt because of the many benefits which it is able to give its learners.

\section{Models of English}

The worldwide English-speaking community has been categorized into three groups [7]. The first group being those for whom English is a native language or mother tongue (ENL). The second group being those who use English as a second language (ESL), and finally, the third group, who use English as a foreign language (EFL).

In this classification, ENL is spoken in countries where English is the primary language of the great majority of the population. Australia, Canada, New Zealand, the United Kingdom, and the United States are countries in which English is said to be spoken and used as a native language. 
In contrast, ESL is spoken in countries where English is an important and usually official language, but not the main language of the country. These countries are typically ex-colonies of the United Kingdom or the United States. Nigeria, India, Malaysia, and the Philippines are examples of countries in which English is said to be spoken and used as a second language.

The final classification of this model is EFL. EFL occurs in countries where English is not actually used or spoken very much in the normal course of daily life. In these countries, English is typically learned at school, but students have little opportunity to use English outside the classroom and therefore little motivation to learn English. China, Indonesia, Japan, and many countries in the Middle East are countries in which English is said to operate as an EFL.

This ENL/ESL/EFL distinction has been helpful in certain contexts. There is no doubt, for example, that the motivation to learn English is likely to be far greater in countries where English plays an institutional or official role than in countries where students are unlikely to hear any English outside the classroom or ever need to use it. This classification, however, has shortcomings. One is that the term "native language" is open to misunderstanding. As speakers in ENL countries are described as native speakers, people feel that the variety used is a standard variety that is spoken by all of the people. People then feel that ENL is innately superior to ESL and EFL varieties and that it therefore represents a good model of English for people in ESL and EFL countries to follow. In actual fact, however, many different varieties of English are spoken in ENL countries. The idea that everyone speaks the same "standard model" is simply incorrect. Second, the suggestion to use ENL as "the model" ignores the fact that such a model might be inappropriate in ESL countries where the local variety would be a more acceptable model, as there are many fluent speakers and expert users of that particular variety.

A second shortcoming of the classification is that the spread of English also means that it is more difficult to find countries that can be accurately classified as EFL countries. As we shall see, English is playing an increasing role in EFL countries such as China and Japan. The ESL versus EFL distinction appears to be more valid when applied to the contrast between city and countryside. City dwellers in both ESL and EFL countries have far more opportunity and need to use English than their rural counterparts. Furthermore, ESL varieties are said to operate in countries that were once colonies of Britain or America, but, the type of colony has influenced the current roles of English in such countries [8].

In ENL countries, even if multilingualism may play an important role in the society at large, English is the vernacular language of almost all or at least a significant majority of the population (like Britain, the USA, or Australia). In ESL countries, English exists side by side with strong indigenous languages, is widely spoken, and assumes prominent intranational, sometimes official functions, as the language of politics, the media, jurisdiction, higher education, and other such domains (as in Ghana, Nigeria, India, Singapore, Malaysia, etc.). In EFL countries, English, acquired almost exclusively by formal education, performs no official internal function but is still strongly rooted and widely used in some domains (like the press or tertiary education) because of its special international usefulness in business, the sciences, technology, and so forth (as in Israel, Egypt, or Taiwan). Of course, the status of English in any given country may change in the course of time. For instance, certain ESL countries have deliberately reduced the role of English to an EFL status [9].

Figure 1 provides a better picture of what has been explained earlier regarding the spread of English beyond the British Isles by Kachru [10]. He describes the varieties of English in the world as forming three concentric circles, that is, the "Inner Circle", the "Outer Circle", and the "Expanding Circle".

The great advantages of this model over the ENL/ESL/ EFL one are, first, that it makes English plural so that one English becomes many Englishes. Second, the model does not suggest that one variety is any better, linguistically speaking, than any other. The spread of English has resulted in the development of many Englishes and not the transplanting of one model to other countries: “... English now has multicultural identities" [11].

The varieties of the English language which developed in the second category have been termed differently by sociolinguists. Kachru, cited in Vethamani [7], uses the term "nonnative varieties", "new Englishes", and "Third World Englishes" whereas Strevens [12], uses the term "Localized Forms of English" and Platt et al. [1], on the other hand, use the term "New Englishes." Despite the different terms used, it is safe to assume that these terms mean the same. Kirkpatrick [8] makes two observations about Kachru's "three circles" model. The first observation is about the use of the term "colony" and the second is about how expanding circle countries are increasing their use of English.

The first observation, as Mufwene [13] has elegantly argued, the type of colony a nation was has influenced the way English developed there, although the developmental processes that each variety went through were similar. Mufwene distinguishes between "trade colonies," "exploitation colonies," and "settlement colonies" [13]. Contact in trade colonies started with European traders and local people. This contact typically led to the development of pidgins. The language varieties that the European traders spoke would have been nonstandard varieties. As these trade colonies became exploitation colonies, they came under the administrative and political control of the respective European nation.

Contact between local and imported languages increased. In the case of many British colonies, for example, the colonizers needed people who could speak English to help administer the colony. They recruited these administrators from three main sources. First, they sent their own people to act in senior positions. Second, they imported administrators from other colonies. Much of the Burmese civil service of the time was staffed by Indian clerks, for example-indeed the Burmese word for chair is "kalathain" and this literally means "foreigner-sit." Foreigners to the Burmese were Indians. Third, the colonizers trained locals as administrators and this necessitated the establishment of special schools where 


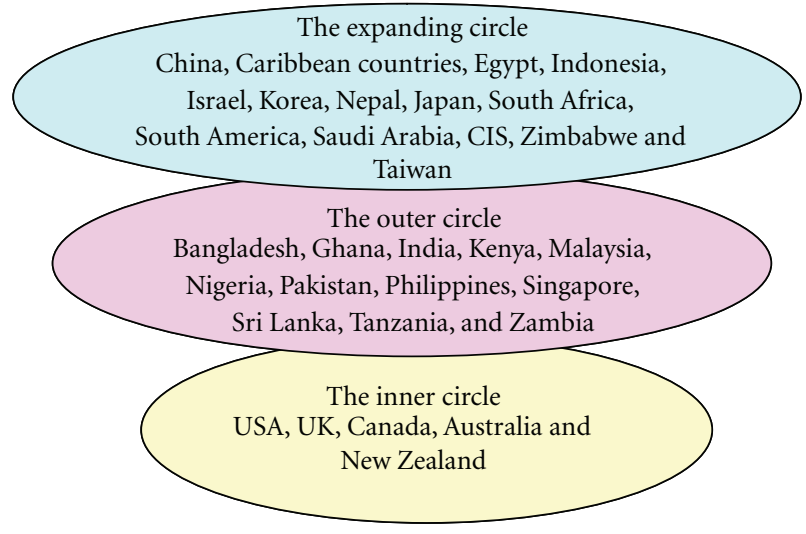

Figure 1: Three concentric circles of englishes [10].

English became the medium of instruction. In such contexts, the variety of English developed through contact with local and other languages and through contact with nonstandard and "school" varieties of English.

In settlement colonies, on the other hand, there was less need to import administrators from other colonies, as the colonizers provided the great majority of the settlers. These settlers, however, brought with them a wide range of varieties. A difference between the Englishes which developed in settlement as opposed to exploitation colonies is the relatively small influence local languages had on the Englishes of the settlers. This is not to say that there was no contact and no influence. In the settlement colony of Australia, for example, local languages provided a wide range of culturally and geographically specific vocabulary items. The comparative lack of contact with local languages, however, meant that there was relatively little influence on the grammar and schemas of the variety as it developed. Interestingly, the grammatical and schematic influences of local languages are reflected in the variety spoken by the indigenous people, Australian Aboriginal English.

In short, in exploitation colonies such as India and Malaysia, the influence of local languages and cultures was greater in the development of the local English varieties. In settlement colonies such as Australia and New Zealand, the same influences were seen in the development of the local variety of English, but to a lesser extent. The difference was in the degree of influence rather than in the type of influence.

The second observation is that it underestimated the roles that English would come to play in Expanding Circle countries, although the term "expanding circle" suggests that the roles of English would develop in these countries. If we take China as an example of an expanding circle country, the increasing roles of English are remarkable. First, it is now being used in education. The number of people learning English in China is now greater than the combined populations of the inner circle countries. In other words, there are more people learning English in China than the combined populations of countries such as the United States, the United Kingdom, Canada, and Australia. Startling as this figure is, it is not as significant as the role
English is beginning to play in formal education. Several Chinese schools and universities now offer courses through the medium of English. In other words, Chinese students are now beginning to be able to study in English.

A second area in which English is playing an increasing role within China is as a lingua franca. China's increase in international trade and contact means that English is becoming the lingua franca of business and trade in China itself. Businessmen from Asia conduct business meetings in China in English. Third, the increased use of computer technology has increased the use of English in computermediated communication. This is not restricted to international communication. Some Chinese are now choosing to use English when sending emails to each other. The increased role of English in this Expanding Circle country is leading to the development of a local Chinese variety of English.

2.1. Emergence of New Varieties. Crystal [14], cited in Schneider [9], claims that the sociocultural changes of the modern period, culminating in the late twentieth century, has been the global spread of the English language, a major component of a "language revolution." For centuries scholars have dreamt of a universal language to communicate with each other directly but all attempts have failed. Instead, English has diversified, developing into homegrown forms and uses in many locations. It has indigenized and grown local roots, thus, the emergence of new varieties.

The emergence and development of nonnative Englishes are either through the colonial education system or through the result of its development from a creole form, as in the case of the West Indies [7]. English was used as a medium of instruction or taught as a subject in educational institutions, through the colonial education system, as in the case of India, Malaysia, and some African nations. The English language was being used in new contexts, it was subjected to change and finally, these new nonnative varieties developed their own distinctiveness, for example, Indian English, Nigerian English, and Malaysian English [7]. These new nonnative varieties differ phonologically, syntactically, and lexically from the established native speaker varieties, such as British, American, and Australian English.

Many scholars have suggested the phases or processes through which varieties of English go. According to Kirkpatrick [8], scholars agree in many areas and that many of the phases identified by one scholar mirror those of another. There are also a number of different terms that refer to the same idea. For example the terms "exonormative model," "transported variety" and "imported variety" refer to the English spoken by the settlers that arrived in a particular country. It is called "exonormative" because the model originates from outside the place where it is spoken. This is contrasted with an "endonormative model," that is, a locally grown variety. If speakers in a country look to one of the norms in their own society as standard, we can call them "endonormative." If they look to a norm outside their own country we can call them "exonormative" [15].

"Transported" or "imported" varieties obviously refer to the varieties spoken by the settlers, as opposed to the varieties spoken by the locals, which are referred to as 
"nativized" or "indigenized" or "acculturated". All varieties are actually nativized in the sense that they all reflect the local cultures of their speakers. This term is also used, however, to distinguish the local variety from the transported variety. The process through which an imported variety goes on its way to becoming a local variety is variously referred to as "nativisation," "indigenization," or a combination of "deculturation" (of the imported variety, as it loses its original cultural roots) and "acculturation" (of the local variety, as it grows new cultural roots).

Kachru has suggested three phases through which "nonnative institutionalized varieties of English seem to pass" [3]. The first phase is characterized by "nonrecognition" of the local variety. At this stage the speakers of the local variety are prejudiced against it and believe that some imported native speaker variety is superior and should be the model for language learning in schools. They themselves will strive to speak the imported, exonormative variety and sound like native speakers, while looking down upon those who speak only the local variety.

The second phase sees the existence of the local and imported variety existing side by side. The local variety is now used in a wide number of situations and for a wide range of purposes but is still considered inferior to the imported model.

During the third phase, the local variety becomes recognized as the norm and becomes socially accepted. The local variety becomes the model for language learning in schools. In places where the local variety has become accepted, local people who continue to speak the imported variety can be seen as outsiders or as behaving unnaturally in some way.

2.2. Moag's Life-Cycle Model. Moag's life-cycle model is another simple and interesting model of nonnative Englishes ([16], republished in [17]) which provides a vivid description of the dynamic changes in the development of Malaysian English. This model is actually based on Hall's model, "life cycle of Pidgin Languages" (Hall 1962 [18], quoted in Moag [16]).

Moag [17] studied the development of a particular variety-Fijian English-and proposed a "life cycle of nonnative Englishes." He identified five processes, four of which are undergone by all varieties, and a fifth which may only be experienced by some. The first process he called "transportation." This is when English arrives in a place where it has not been spoken before and remains to stay.

The second process, "indigenization," is a relatively long phase during which the new variety of English starts to reflect the local culture and becomes different from the transported variety. The third process, the "expansion in use and function" phase, sees the new variety being used in an increasing number of situations and for more and more purposes. This process is also marked by an increase in variation within the local variety. The local variety becomes the local varieties. The fourth phase is marked by the use of the local variety as a language learning model in school. During this phase, local literature in the new variety will be written. Moag calls this fourth phase "institutionalization."
The fifth and final phase, "restriction of use and function" sees a decline in use. He suggests that the Philippines and Malaysia are examples of countries where the increased official promotion of a local language-Tagalog in the Philippines and Malay in Malaysia-results in a decline in the use of the local variety of English. He wonders whether this decline in use might lead to the eventual death of English in these countries, but there is no evidence of that happening. In fact, in the Malaysian context, there has recently been an officially approved and promoted increase in the uses of English.

Vethamani [7] claims that there is not only the fifth process but also a sixth process in the case of Malaysian English. He refers to it as "reestablishing of English." Asmah [19], one of Malaysia's leading linguists, uses the term "reestablishing English" to describe the reemergence of English in Malaysia. She sees the return of English not as having come "a full circle" because it has not been accorded the status it had enjoyed during the colonial period and early postindependence period. She is of the view that the reemergence of enthusiasm for the English language is in line with the role of the language in the development of the country. The English language which had been associated with colonial rule became unfashionable following independence, but has reemerged as a language for international communication and knowledge. With the firm establishment of Bahasa Malaysia as the national language, English is no longer seen as a threat to national unity [20]. Figure 2 provides a vivid description of the dynamic changes in the development of Malaysian English.

2.3. The Dynamic Model. In comparison with earlier models of Postcolonial Englishes (PCEs), the Dynamic Model by Schneider [9] offers several innovative qualities and advantages. Firstly, it is holistic in imposing an overarching and unifying perspective, as against the static and individualizing typologies of earlier approaches. It thus reinterprets isolated observations and case studies as situated in a coherent framework, relating them to each other and to relevant linguistic theories in a systematic fashion. Secondly, it adds an essential dynamic dimension to earlier static classifications, regarding differences between varieties of English as instantiations of characteristic phases of an underlying uniform process. The postulation of this single evolutionary process underneath what we see emerging at various locations independently of each other all around the globe is a provocative, innovative assertion in itself. Thirdly, the model adopts the speech community rather than the nation state as its sociolinguistic unit of description. By distinguishing between Settlers speech community (STL) and Indigenous speech community (IDG) strands and by allowing for speech differences between ethnic, social, and regional communities, it is thus descriptively more adequate and can be more finely tuned and adjusted than the ENLESL-EFL or Three Circles model, which overlook intranational differentiation. The five distinct phases involved are "Foundation," "Exonormative Stabilization," "Nativization," "Endonormative Stabilization," and "Differentiation". 


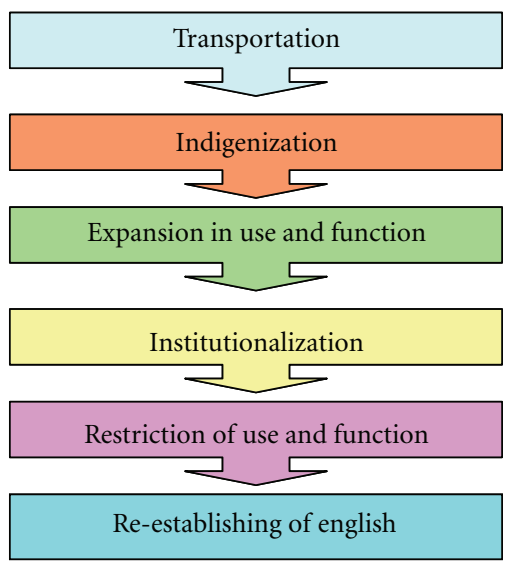

Figure 2: Life cycle of nonnative Englishes [7, 16].

The five distinct phases involved are "Foundation," "Exonormative Stabilisation," "Nativisation," "Endonormative Stabilisation," and "Differentiation". Table 1 summarises the main phases of this model and the following sections discuss the phases related to Malaysia.

\section{Malaysia: Phases 1 and 2 (1786-1957)}

The British came to South-East Asia late in the eighteen century to secure trading outposts and to challenge the economic and political power of other European nations in the region, most notably the Dutch [9]. Throughout much of the nineteenth century, until Malaya gained the status of a crown colony in 1889, the colony was governed from India, which accounts for quite some impact of Indian English in the early shaping of its variety through the immigration and employment of many Indians, for instance as teachers in English-medium schools [21]. Throughout the second half of the nineteenth as well as the early phase of the twentieth century the British influence expanded politically and geographically, if only rather slowly. Malaya was originally a trade colony in Mufwene's [22] terms, that is, British immigrants performed functions in the interest of the Empire and their trade company but did not perceive themselves as settlers in the strict sense.

Large-scale population movements caused by the British during that period are the basis of Malaysia's presentday multicultural makeup. Notwithstanding migrations of smaller groups and the presence of indigenous "Bumiputra" (Malays and Aboriginal groups), two major ADS (Adstrate speech community) groups were attracted; mostly throughout the second half of the nineteenth century Chinese people came to work in the tin mines; and predominantly the early twentieth century saw the immigration of Indian (primarily Tamil) workers to labor in the rubber plantations. In addition, the British colonial government provided incentives for smaller groups to migrate as well and to bring into effect their own special skills_like the Punjabi Sikhs, who originally constituted a large portion of the police force.

Conversely, it is clear that the indigenous rulers accepted an English education for their sons and also daughters as an enriching contribution to their enduring local roots and status. Consequently, in the IDG (Indigenous speech community) strand bilingualism spread continuously, although locally it remained largely associated with elitism and reserved to a minority [9].

Essentially, formal access to English was a privilege to those of higher status amongst the indigenous population. This attitude is epitomised by the establishment of the Malay College of Kuala Kangsar in the 1920s, a boarding school reserved for the sons of the Malay rulers and those of noble birth which nurtured civil servants and top administrators [23]. Similarly, the foundation of a corresponding girls' school, the MGC in Kuala Lumpur as late as in 1947, was originally meant to educate suitable partners as matches for the local elite. Education at these institutions implied complete immersion into English. Thus, "when the British began to withdraw from the area in the late 1950s, English had become the dominant language of the non-European elites, both as a language of power and prestige and as an inter-ethnic link language" [24]. This educational policy had long-lasting effects that went beyond what the British had in mind, English-medium education in these institutions created interethnic bonds and established a value system that soon thereafter paved the way to a desire for independence.

According to Schneider [9], in a global British perspective the Chinese and Indians, together with the original Malays, constituted the Asian, indigenous population. To date, both groups (the Chinese and Indians) have typically adopted English as their vernacular more readily than the Malays have. The earliest and most persistent foreign elements that entered English were mainly toponyms, while a few localities important to the British were given English names (like Georgetown, Cameron Highlands, Port Dickson, or Fraser's Hill), places names are overwhelmingly indigenous in origin (like Penang, Selangor, Perak, Seremban, Kuala Terengganu, Kota Bahru, and may others). Soon these were followed by indigenous borrowings for fauna and flora, (orang-utan, for which the Oxford English Dictionary gives an earliest citation date of 1631, rusa "kind of deer" 1783, kanchil "species of chevrotain" 1829, tupai "Malaysian squirrel" 1820, seladang "gaur" 1821, mengkulang "timber tree" 1940) and culturally significant terms (temenggong "high-ranking official" 1783, adat 1783, tuak "palm wine" 1850 , mee goreng, merdeka 1954, etc.).

\section{The Impact of Malaysia's Nationalist Language Policy}

With the constitution of 1957, English was retained as a coofficial language in addition to Malay, but the pronounced intention was to develop Malay into a national language and to remove this special status of English after a tenyear transition period. The official status of English ceased in peninsular Malaysia in 1967, in Sabah in 1973, and in Sarawak in 1985 [23]. Formally, the "National Language Act of $1976 \ldots$ disestablished English as the joint official language, giving sole status to Malay" [25].

The policy of replacing English by Bahasa Malaysia was also an element in the power struggle between the Malays and 


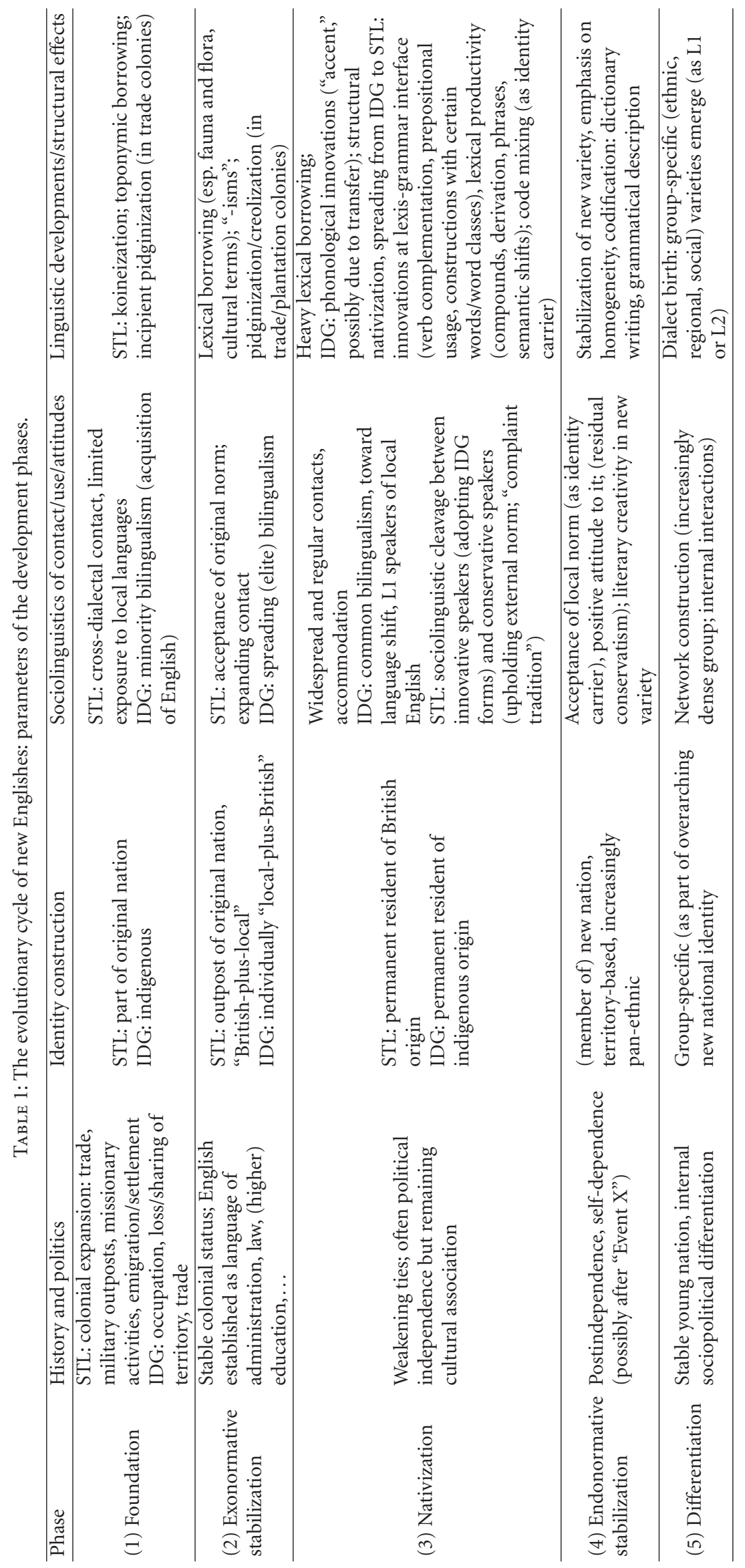


the successful and increasingly influential Chinese and South Asians [24]. Depriving English of its formerly privileged status was a logical and in a sense an unavoidable step on the side of the government, as Gill [25] points out-otherwise, no room would have been left for the full development of Bahasa Malaysia. In practice the most important step in the implementation of the new policy was the Ministry of Education's decision to turn all English-medium schools into Malay-medium, beginning in 1969, a process which was completed, reaching university entrance level, by 1983 . Today, it is widely accepted that Bahasa Malaysia has securely established its position as a truly national language [26].

Former Prime Minister Dr. Mahathir's policy of "Vision 2020," the goal of turning Malaysia into a fully developed country by that year which implied emphasis on globalisation and technological advancement requires full fluency in English on the side of Malaysian engineers and business people, amongst others. Consequently, the Education Act of 1996 approved of the reintroduction of English as a medium of instruction in technical subjects. On the other hand, the Malay Intellectual Congress, resisted the early proposals in 1993 to reintroduce English as a medium of instruction in the sciences, arguing that it would weaken the further development of the Malay language. Hence, it was only in 2003 that the new English-medium policy for teaching Mathematics and the Sciences was put into effect. In sum, Malaysia's recent language policy has been marked by nonlinear developments and opposing tensions and tendencies, and it is too early to predict its long-term effects.

\section{Phase 3 (1957-)}

Despite the obstacles, however, Malaysian English has proceeded into phase 3: nativisation. In terms of its sociolinguistic status and domains of usage, English is still widespread and deeply rooted in the country, mostly in urban environments. Bilingualism and multilingualism in English, Malay, and further ethnic languages are common. English still holds a very strong position in interethnic communication. "The mesolect is the variety that is used for intranational communication between Malaysians of varying ethnicity, as a medium of local communication" [25].

English is widely available for daily exposure and easy acquisition, with respect to passive language skills. It is readily accessible in the mass media, through radio, $\mathrm{TV}$, and newspapers [27]. It is noted that 31.6 percent of all radio listeners listen to English radio stations [25]. Asmah [23] argues that English is also acquired naturally, even though passively, by children in the kampungs through watching popular TV blockbusters. She claims that they tend to understand the English TV programs well even if they cannot speak in English. Some early, informal acquisition of English also operates through the influence of elder siblings even in non-English speaking families [21]. And finally, the fact that basilectal English is also used by blue-collar workers, as shown by Morais [28] and others, testifies to the range of informal domains into which Malaysian English has diffused.
Nativised English is acceptable for communicating socially and informally and gives one a strong sense of identity [25]. This is reflected by the distinct phonology influenced by their ethnic tongues, lexical items which are socioculturally grounded, and syntactic structures which are distinctly Malaysian in form. This is to create rapport and establish a sense of identity [25]. Colloquial Malaysian English (ME) is often the preferred choice, as a sign of solidarity and camaraderie, even for speakers who are highly proficient in standard English [29].

Actually, trying to adopt a "native speaker," foreign accent is usually rejected as "put on" [30]. An interview conducted by Schneider [31], with a group of Malaysian students showed that a "good accent," that is, British or American, is a goal worth striving for and displays a deeply entrenched exonormative orientation. However, they rejected the binarism implied in a statement like "Malay and English are both essential in nation-building" [23], and also the exclusive focus of Malaysia's language policy upon these two languages. Conversely, particularly students of non-Malay descent said that they would like to see their own ethnic native languages recognised more generally as important elements of the country's heritage and reality. Laments on "falling standards of English" [32] by the public are commonly voiced in English-language newspapers.

Malaysian English has undergone structural nativisation on all levels of language organisation. Phonological features include vowel mergers, accent shifts, suprasegmental feature like intonation and a syllable-timed rhythm, the omission of single coda consonants, and final consonant cluster reduction [33]. Many of the grammatical innovations are attested at the interface of lexis and syntax. "Many of these features... involve the selection of complement structures following particular verbs, adjectives, and so forth... the use of phrases where clauses would be usual in other varieties" [34]. The local vocabulary has incorporated borrowings from indigenous languages [35]. This includes culturally distinctive terms (e.g., tudung, kampong, sawi, bomoh, and penghulu), words for different kinds of ethnic food (e.g., sambal, kacang, mee), hybrid local compounds (e.g., meranti wood, syariah court, and nobat drums), coinages (e.g., Datukship), semantic shifts (e.g., cut), and local collocations (e.g., open light/socks/tap/hooks). Lowenberg [24] shows that Malaysian policy thrives upon what he calls "banner words," terms loaded with political and cultural significance in public discourse (e.g., gotong-royong, adat, bumiputra, and rakyat). David [36] probes into another segment of vocabulary which is both regionally and socially restricted, namely, newly emerged adolescent in-group slang (e.g., dungu "stupid," wasted sperm "useless individual," chun "nice," lepak blues, bang "criticise," slambar "relax," or Like reallah!).

Another feature closely associated with phase 3 is the emergence of code shifting and code mixing as a communicative device. There are signs that this "mixed code" is assuming the role of a positive identity carrier, either in addition to or replacing Malay and/or mesolectal English in that social function $[24,27,36]$. In the interview mentioned above, the Malaysian students stated that code mixing is the most natural way of using and choosing between languages 
and felt it to be a most direct expression of their personalities [31].

\section{Beyond Phase 3}

It would be futile to claim that Malaysia has moved or is moving beyond phase 3 of the Dynamic Model, but traces of even later phases can be seen. Halimah and $\mathrm{Ng}$ [37] address the issue and possibility of accepting certain elements of Malaysian English (ME) usage as correct in the education system. Gill [38] advocates the development of endonormative standards, and Gill [25] presents a strong case for a future codification of ME, talking of the need to develop "our own standards, for example, Standard Malaysian English" [25]. She argues for educated nonnative English as a pedagogical model [25] and the existence of a "pragmatic postindependence/endonormative phase" of ME [25]. Literary creativity, another indicator of the acceptance of a local variety, in $\mathrm{ME}$ is documented and surveyed, for instance, by Merican [39]. Codification entails the production of dictionaries. A distinct lexicographic coverage of ME, together with Singaporean English, has begun with the publication of the second edition of the Times-Chambers Essential English Dictionary [40] and with the inclusion of Malaysian words in the Macquarie Junior Dictionary [41] and the Grolier International Dictionary [42].

\section{Developmental Cycles of New Varieties of English}

The developmental cycles of new varieties of English based on three main models by three main scholars, namely, Kachru, Moag, and Schneider have been discussed. All three scholars have suggested developmental cycles that have their similarities. These can be seen in Table 2.

Basically, the variety spoken by the settlers becomes changed over time through contact with local languages and cultures. The new indigenous variety is initially considered inferior to the original imported one, but gradually it becomes accepted and institutionalised. Once it is accepted and institutionalised, it then develops new varieties [8].

According to Mufwene and Schneider, all varieties of English develop from similar stimuli and through similar processes. All varieties must, on the one hand, reflect the cultural realities of their speakers and, on the other, be adaptable enough to allow international communication.

\section{Indigenisation of English in Malaysia}

The focus of this study is on the second process, that is, the indigenization or nativization of English in Malaysia. This process occurs in two phases [7]. The first phase involves a number of local words being drawn into the English language by "English speaking newcomers." These words are often cultural specifiers which do not have proper and exact equivalents in the English language [43]. Moag further claims that, during the first phase, the borrowings remain very much at the lexical level. This is because the local learners are subjected to native speaker models of English and due to this, only specific local terms are allowed into the English language.

The second phase of the indigenization process occurs in two ways. Firstly, English is used in a lingua franca, a link language for people from different language backgrounds to work together in the colonial system [7]. According to Moag [16], more native features are incorporated into English as the locals "bring familiar items and conventions in their own languages and cultures into play in the new situation." Secondly, he also claims that the English language becomes the preferred language to discuss topics which are unfamiliar or that are related to culture. Since Malaysia is a multiracial country, a complementary dialect of English for intergroup communication emerged in Malaysia schools. This variety is characterized by features found in the home dialects of the pupils, especially those of Malay, Chinese, and Indian origin [44]. This influence can be clearly seen in their spoken and written language. Therefore, Malaysian English has a lectal continuum ranging from the educated form to the uneducated or substandard variety [45]. The "acrolect" is the most standard and highest form, the "mesolect" is used in informal situations and the "basilect" is the most substandard variety, as shown in Figure 3.

Wong [46] considers the acrolectal variety or Standard Malaysian English to model itself after the standard formal and written native speaker variety of English, that is, the British English. The acrolectal variety is the variety which ought to be taught and learnt in the Malaysian schools [47].

"The mesolect is the variety that is used for intranational communication, between Malaysians of varying ethnicity, as a medium of local communication" [25]. The "basilect" is the English of low-proficiency learners, characterized by limited vocabulary and efficiency as a means of communication [15].

During the twentieth century the Malay Peninsula was a multilingual society. The Malays spoke different local varieties of Malay and used a standard written form; the Chinese used their "dialects," the Indians Tamil and other Indian languages, and the colonial authorities used English. Arabic and Sanskrit were known as languages of religion. A lingua franca variety of Malay, "Bazaar Malay", and types of English functioned as link languages. English was spread by the education system and educated people became very fluent because they used the language for everyday communication across communal boundaries. Less educated people in towns also used English for this purpose. The result was that lingua franca English existed in a range of varieties from an "acrolect" which was a Standard English with local phonology to a "basilect" which had many of the characteristics of an extended pidgin or creole. Because more basilectal varieties were used in the school playground, they began to connote intimacy for many people who also mastered the acrolect, and the lectal range from standard to markedly local began to imply a stylistic range from formal to informal [15].

The contact between English and other languages in Malaysia, especially Bahasa Malaysia, has given rise to lexical borrowings, code mixing, and code switching [7]. Lexical borrowing is evident in the formal and acrolectal level whereas code mixing and code switching are more evident 
TABLe 2: Developmental cycles of new varieties of English [8].

\begin{tabular}{|c|c|c|c|c|c|c|}
\hline \multirow{2}{*}{ Scholar } & \multicolumn{6}{|c|}{ Phases } \\
\hline & 1 & 2 & 3 & 4 & 5 & 6 \\
\hline Kachru [3] & Nonrecognition & $\begin{array}{c}\text { Coexistence of local } \\
\text { and imported varieties }\end{array}$ & Recognition & - & - & - \\
\hline Moag [17] & Transportation & Indigenisation & $\begin{array}{c}\text { Expansion in } \\
\text { use }\end{array}$ & Institutionalisation & $\begin{array}{l}\text { Restriction of use } \\
\text { and function }\end{array}$ & $\begin{array}{l}\text { Reestablishing } \\
\text { of English }\end{array}$ \\
\hline Schneider [9] & Foundation & $\begin{array}{l}\text { Exonormative } \\
\text { stabilisation }\end{array}$ & Nativisation & $\begin{array}{l}\text { Endonormative } \\
\text { stabilisation }\end{array}$ & Differentiation & - \\
\hline
\end{tabular}
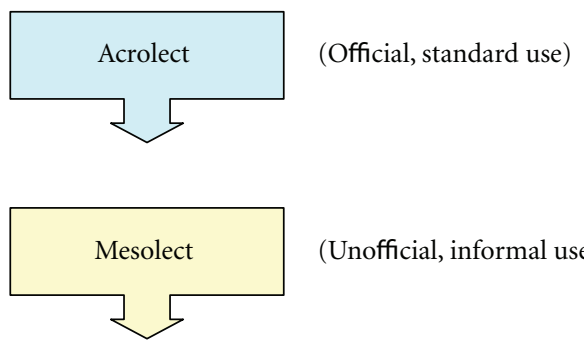

(Unofficial, informal use)

Basilect

(Broken Malaysian English, substandard use)

FIgURe 3: The three levels of the lectal continuum [45].

in the informal or colloquial and basilectal level [1, 45]. Malaysian English has an identity of its own and the many deviations in the lexical aspects make it a distinct variety of English. According to Wong [48], "nonnative speaker of English should never be made to feel ashamed of their own variety of the language, no matter how deviant it may be from native speaker English."

The problem arises when one has to consider which lexical items are accepted in the standard Malaysian English and which are not. The ones which are cultural specifiers which do not have proper and exact equivalents in the English Language are the accepted ones. However, students are ignorant of this and they tend to use words, especially from Bahasa Melayu, whenever they have difficulties expressing themselves in English. Some of the variations in lexis, in the Malaysian English, are discussed in detail in the following sections.

8.1. The Acrolect: Borrowing. At the level of the acrolect, English in Malaysia is marked by frequent borrowing of lexical items from Bahasa Melayu. As mentioned earlier, most borrowings in the acrolect level are due to the absence of exact equivalents in the native speaker varieties.

The use of Malay titles of address for persons of high rank or status in the NST is one way to portray nationalism. For example, although the Malaysian heads of the state are often referred to by the English titles king and queen, they are also mentioned in the NST by their Malay titles, "Yang di Pertuan Agong" and "Raja Permaisuri Agong" [49].
Yang di-Pertuan Agong Tuanku Mizan Zainal Abidin opened the fourth session of the 12th Dewan Rakyat here today.

Tuanku Mizan was accompanied by Raja Permaisuri Agong Tuanku Nur Zahirah.

(NST, 7 March, 2011)

The term "rakyat" (the people), portrays national identity, just as titles of address [49]

"It ignited a new passion and enthusiasm among many civil servants and challenged others to realize their full potential and responsibility to the rakyat," Najib said.

(NST, 28 March, 2011)

Another borrowing, is the term "Bumiputera" (sons of the soil), which refers to ethnic Malays especially when discussing commercial, political, and educational plans and programmes [49]

Majlis Amanah Rakyat (Mara), a government agency set up to develop Bumiputera entrepreneurs, is venturing into the property business as it seeks to rely less on the government for funding.

(NST, 9 March, 2011)

"Dadah" (drugs, medicine) is another Bahasa Melayu borrowing found regularly in the press. It is almost always restricted in meaning, in a sense that, it refers to only illicit drugs and narcotics [49]

Curious parents and their children also converged at the police exhibition, which featured antidadah, anti-crime and road safety campaigns. A police mobile unit was also present.

(NST, 8 March, 2011)

"Gotong-royong" means a form of communal cooperation which refers to institutions with characteristics unique to the Malay speakers [50]

Petaling Jaya City Council (MBPJ) plans to have a gotong-royong at different locations once a month in SS2.

(NST, 13 January, 2011)

A "kampong" in Malaysian English expresses a different concept from a European "village" and it is more than can be expressed by the more neutral term "small settlement." It relates to a closely structured community with a definite community life and feeling of belonging [1] 
Razi has been shaking hands with kampong folk and traders in his kawasan since Wednesday.

(NST, 10 April, 2011)

Another form of nativization is also apparent in Malaysia. Since the Malays form the largest ethnic group in Malaysia, their religion of Islam has become an increasingly influential force in the Malaysian context of culture. This can be seen in the NST by the use of Islamic terms borrowed into Bahasa Melayu from Arabic, such as "halal" (lawful, pertaining to food), [49]

Towards efforts to enhance Malaysia's position as the global halal hub, the Halal Malaysia Week 2011 will emphasize the Incoming Buying Mission programme.

(NST, Business Times, 26 January, 2011)

"Saree/sari", dhoti, dhal and curry' are some of the other examples of lexical borrowings from the Tamil language and 'ang pow, cheongsam, tai chi, feng shui and pagodas are from the Chinese dialect. The examples are illustrated in the sentences below:

Undergraduate Dinitha Ambiga beat 11 other contestants to win the Miss Saree Queen 2010 (Perak) beauty pageant, held here on Saturday night.

(NST, 18 October, 2010)

Pure silk dhoti in shades of pink, yellow and orange priced between $R M 600$ and RM1, 500 were also in big demand. Silk for statues in temples as well as the priests were also popular.

(NST, 18 May, 2011)

Thosai is a common South Indian meal which comes in many varieties, flavours and with various curries, chutneys and dhal.

(NST, 29 July, 2006)

There are several venues to enjoy a tasty curry fish head meal in Penang. One worthy place to check out is Chee Wah.

(NST, 22 Nov, 2010)

Little red packets containing money known as ang pow are traditionally given by married adults to children during Chinese New Year, or given as gifts during Chinese weddings.

(Borneo Post, 16 January, 2011)

A 19-year-old Hokkien girl from Kuching, Wee Pek Choo won the Miss Cheongsam Charity 2011 at the Riverside Majestic Hotel on Wednesday evening, beating 18 other finalists to the title.

(Sarawak Tribune, 18 February, 2011)

At 87 , she is the oldest person practising tai chi in Seremban Lake Gardens.

(Star, 14 May, 2011)
When Lillian Too speaks on feng shui, people listen. And they are willing to pay for it, sometimes as much as US\$10,000 (RM33, 480).

(Star, 16 January, 2010)

The multi-storied pagoda symbolizes the five universal elements of earth, water, fire, air and ether.

(NST, 17 February, 2011)

8.2. The Mesolect: Mixing. Most Malaysians are bilingual or multilingual. "The phenomenon of code-switching among bilingual and multilingual has been one of the most fascinating and intriguing topics in synchronic linguistics in the last fifteen years" [51]. Mesolect mixing refers to "lexicalization quite prevalent even for words having international substitutes" [45]. Below are a few examples:

\section{A tidak apa type}

Never mind, couldn't care less [52]

ulu

"Cause this is quite an ulu area, $y$ " know [53]

(implying "I'm stuck here, away from the main business and shopping areas")

This word derived from the Bahasa Melayu word "hulu" which means "upstream, upper part of a river, rural area" [53].

8.3. The Basilect: Mixing. Basilect mixing refers to "major lexicalization-heavily infused with local language items" [45]. Below are a few examples:

Die lah I like this. (Matilah aku macam ini.)

What lah you! You cannot put your car like this. (Apalah engkau ni! Engkau tak boleh letak kereta macam ini.) [43].

The example above is a literal or direct translation from Bahasa Melayu. The word or particle "lah" is the most frequently used item in this form of English. It has various meanings, depending on the way it is pronounced. It can function as an intensifying particle, as a marker of informal style, as a signal of intimacy, for persuading, deriding, wheedling, rejecting, and many other purposes [54]:

Alamak! Kena fine again [53].

The word "alamak" is used as an exclamation. Depending on the intonation it may express surprise, derision, or annoyance [53]:

I am trying to study, tapi tak boleh.

Charleston is so boring kalau you tak ada [24].

\section{The Lectal Varieties of Malaysian English}

The examples cited are some of the variations in lexis in Malaysian English. In the English language classroom, teachers need to identify the lexical borrowings which are evident 
in the students' spoken and written discourse in order to guide them to achieve international intelligibility. According to Baskaran [45], the variation in lexis is acceptable especially for words not substitutable in an international context, in order to give a more localized context. If this is the case, the, students ought to be made aware of which lexical borrowings are acceptable and which are not, students should not be allowed to use lexical borrowings, especially Bahasa Melayu, just because they have difficulties expressing themselves in English. In other words, students are allowed to use the "Acrolect: Borrowing" but not the "Mesolect and Basilect: Mixing" in their spoken and written discourse.

The acrolect (official Malaysian English), which is at the highest level in the continuum, is the standard form which is grammatically similar to standard British English. However, it is neither spoken with the same pronunciation nor with the prosodic features of the native speaker's standard variety of English. It is considered the prestigious form of English, either spoken or written, which is appropriate for formal context and is internationally intelligible [45].

The mesolect, which is in the middle of the continuum, allows more variation in the areas of phonology and lexis. The quintessence of indigenisation lies at this level [55]. Due to simplification and generalisation, this substandard variety of Malaysian English lacks well-formedness. This variety is used in informal situations and is considered a local dialect. It is used to establish a rapport between the speaker and the hearer in Malaysian English [56].

Finally, at the lowest end of the continuum is the basilect. Baskaran [45] states that this lect is only found in the spoken form and is regarded as "broken Malaysian English." According to Baskaran [45], due to the deviation in phonology, syntax, and lexis, the basilect is only intelligible among speakers who can communicate at this level.

Vethamani [7] adds that ".. an acrolectal speaker would have the ability to move down the lectal scale and speak on a mesolectal or basilectal level...." He also claims that the lect switch is "a unidirectional downward switch" which means that the mesolect speaker would be able to switch to the basilect but the basilect speaker would be unable to switch to either the mesolect or the acrolect. Table 3 provides a summary of the lectal varieties of Malaysian English.

\section{Current Status of English in Malaysia}

Malaysian English has an identity of its own and the many deviations in these lexical aspects make it a distinct variety of English. According to Wong [48], "nonnative speaker of English should never be made to feel ashamed of their own variety of the language, no matter how deviant it may be from native speaker English."

Currently in Malaysia, English is used for some tertiary education, and quite widely as the language of business, where many firms are still dominated by Chinese or Indian personnel. Nair-Venugopal [27], Gill [38], and Morais [57] examined workplaces in Malaysia and showed that English is frequently used, often with code switching into Malay and variation between standard and more localized forms according to situation and conversational partners. In
2002 the government, eager to benefit from globalization, signalled a swing back to English-medium primary and secondary education, at least for science and mathematics.

Recently [58], Malaysia came out tops for English proficiency among Asian countries where English is not the mother tongue. The Education First English Proficiency Index (EF EPI) is an international education company that specialises in language training, educational travel, academic degrees, and cultural exchange. In the EF EPI 2011 report released on March 30, Malaysia overtook Hong Kong (at second place), South Korea (third place), and Japan (fourth place). Malaysia is the only Asian country rated as "high proficiency" for the English proficiency level in the report. All the countries were rated at five different levels - very high proficiency, high proficiency, moderate proficiency, low proficiency, and very low proficiency.

Malaysia is also ranked ninth place globally among 44 countries listed with a 55.54 score (high proficiency level). Education First, a global education centre, conducted online English tests on 2.3 million working adults globally from year 2007 to 2009. English proficiency was tested in four categories: grammar, vocabulary, reading, and listening. The EF EPI measures the average English proficiency of an entire country and compares English skill levels between countries. It was the first index of its kind to give countries a standardised measure of English competency in adults. Deputy Education Minister Datuk Dr. Wee Ka Siong was happy with the results but said there was still room for improvement. He also pointed out that "Although we topped other Asian countries, we are still in the ninth place globally. I believe with the ministry increasing the period for English language in schools, it will help out students to improve their command of English" [59].

Asked whether the ranking will bring back the teaching of Mathematics and Science in English (PPSMI), he said the ministry would look into the possibility. MCA president, Datuk Seri Dr Chua Soi Lek had said that PPSMI should be allowed to continue especially in selected urban schools where adequate qualified teachers were available. He added that teaching both subjects in English was crucial if the country wishes to move towards a developed nation status. Prime Minister Datuk Seri Najib Razak, said that the government would study the possibility of using two mediums of instructions in the teaching of Science and Mathematics in schools. Last July, the cabinet decided the medium of instruction for Mathematics and Science would revert to Bahasa Malaysia in national schools and mother-tongue languages in national-type schools from 2012 onwards.

About 300 Fulbright scholars from the United States will be in Malaysia from next year to help improve English proficiency among school children in urban and rural areas, including Sabah and Sarawak [60]. The Fulbright programme is the flagship international educational exchange programme sponsored by the US government. It is designed to increase mutual understanding between the people of the US and those from other countries.

Education Minister Tan Sri Muhyiddin Yassin said the education initiative, under the Fulbright English Teaching Assistance programme for fun learning, had been agreed 
TABLe 3: Lectal varieties of Malaysian English [45].

\begin{tabular}{|c|c|c|c|}
\hline Sociolinguistic & Official ME (Acrolect) & Unofficial ME (Mesolect) & Broken ME (Basilect) \\
\hline Linguistic & $\begin{array}{l}\text { Standard ME } \\
\text { (Spoken \& Written) } \\
\text { Formal Use } \\
\text { International intelligibility }\end{array}$ & $\begin{array}{l}\text { Dialectal ME } \\
\text { (Spoken \& Written) } \\
\text { Informal Use } \\
\text { National intelligibility }\end{array}$ & $\begin{array}{l}\text { Patois } M E \\
\text { (Spoken only) } \\
\text { Colloquial use, patois intelligibility \& } \\
\text { currency }\end{array}$ \\
\hline Phonology & $\begin{array}{l}\text { Slight variation tolerated so long as it } \\
\text { is internationally intelligible }\end{array}$ & $\begin{array}{l}\text { More variation is tolerated-including } \\
\text { prosodic features especially stress and } \\
\text { intonation }\end{array}$ & $\begin{array}{l}\text { Severe variation-both segmental and } \\
\text { prosodic, with intonation so } \\
\text { stigmatized-almost unintelligible } \\
\text { internationally }\end{array}$ \\
\hline Syntax & No deviation tolerated at all & $\begin{array}{l}\text { Some deviation is acceptable although } \\
\text { it is not as stigmatized, as broken } \\
\text { English, (intelligibility is still here) }\end{array}$ & $\begin{array}{l}\text { Substantial variation/deviation } \\
\text { (National Intelligibility) }\end{array}$ \\
\hline Lexis & $\begin{array}{l}\text { Variation acceptable especially for } \\
\text { words not substitutable in an } \\
\text { international context (to give a more } \\
\text { localized context) }\end{array}$ & $\begin{array}{l}\text { Lexicalization quite prevalent even for } \\
\text { words having international substitutes }\end{array}$ & $\begin{array}{l}\text { Major lexicalization-heavily infused } \\
\text { with local language items }\end{array}$ \\
\hline
\end{tabular}

upon by the Federal Government and the United States. Through this programme, it is hoped that the level of proficiency in the language among our students could be brought to new heights. The Terengganu state government had embarked on a similar programme on its own initiative and it had proved successful. Under the first phase, 50 scholars would start by the year 2012. Under the programme, the American scholars would assist in the teaching of the language on a volunteer basis. They will go to the ground (schools), but they will not teach the English subject as there are already teachers to do this. Instead, they will teach English-related fun programmes or activities to encourage students to speak in English during certain school hours which will be determined later. Therefore, the students' timetable will not be affected.

This programme is unlike the master teachers' programme between Malaysia and the United Kingdom where master teachers guide Malaysian teachers who teach Englishrelated subjects. These master teachers will work closely with the school authorities on how best to improve the language, like the method of teaching. These master teachers go to a school for a week or so and assist teachers in areas where improvement needs to be done.

Lately, there have been a lot of issues in the newpapers regarding the English language in Malaysia. The "To Uphold Bahasa Malaysia and to Strengthen the English language" (MBMMBI) policy, to be introduced by the Education Ministry next year, aims to do so in line with the government's aspirations to make Bahasa Malaysia (BM) both a medium of unity and solidarity, as well as the main language of communication and science. At the same time, measures will also be taken to enhance proficiency in English (BI) so as to enable students to compete and explore new knowledge at national and international levels. The enculturation and mastery of English from school will also help in efforts to foster national unity and develop a new economy in a globalised, dynamic, and increasingly challenging world (NST 23 September 2011: 14) [61]. It is difficult to deny that both languages have an important role to play in producing human capital with the knowledge, skills and competency to drive a knowledge-based economy.

These are some of the many steps taken to improve the standard of English in Malaysia. This clearly shows that the English language is given importance lately.

\section{Conclusion}

In conclusion, this paper provides a brief description on the aspects of Malaysian English lexis: the acrolect borrowing, the mesolect, and basilect mixing. "All the levels of Standard English, where transfer is primarily lexical, borrowings from Bahasa Malaysia can be used to foreground or to neutralise particular identities, statuses, and privileges" [50]. At the more colloquial range of Malaysian English, transfer includes not only borrowing but also code mixing and switching as bilingual and multilingual speakers and writers use them to portray informality, familiarity, rapport, humour, and again ethnic identity [50]. This clearly portrays that, nativisation in the institutionalised variety of English in Malaysia results not from "fossilized approximations of native speaker norms but from communicative strategies appropriate to these nonnative contexts of language use" [49].

\section{References}

[1] John Platt, Heidi Weber, and Lian Ho Mian, The New Englishes, Routledge \& Keegan Paul, London, UK, 1984.

[2] English Language, (2007-2011) "English Language History" http://www.englishlanguageguide.com/english/facts/history/.

[3] Braj B. Kachru, The Other Tongue: English across Cultures, University of Illinois Press, Urbana, Ill, USA, 2nd edition, 1992.

[4] Braj B. Kachru, "Models for non-native Englishes," in The other Tongue: English Across Cultures, University of Illinois Press, Urbana, Ill, USA, 1982.

[5] C. Brumfit, "English as an international language I: what do we mean by 'English'?" in English for International Communication, Christopher Brumfit, Ed., Pergamon Press, Oxford, UK, 1982. 
[6] Larry E. Smith, Ed., Readings in English as an International Language, Pergamon Press, London, UK, 1983.

[7] Malachi Edwin Vethamani, Character Presentation and Interaction: Styles of Minority Discourse in the Malaysian English Novel, Ph.D. thesis, University of Nottingham, 1996.

[8] Andy Kirkpatirck, World Englishes: Implications for International Communication and English Language Teaching, Cambridge University Press, Cambridge, UK, 2007.

[9] Edgar W. Schneider, Postcolonial English: Varieties Around the World, Cambridge University Press, Cambridge, UK, 2007.

[10] Braj B. Kachru, Teaching World English Without Myths. In Intelec '94, Perpustakaan Negara Malaysia, Kuala Lumpur, Malaysia, 1994.

[11] Braj B. Kachru, "Standards, codification and sociolinguistic realism: the English language in the outer circle," in English in the World: Teaching and Learning the Language and Literatures, Quirk Randolph and Henry G. Widdowson, Eds., pp. 11-30, Cambridge University Press/The British Council, Cambridge, UK, 1985.

[12] Peter Strevens, "The localized forms of English," in The other Tongue: English Across Cultures, Braj B. Kachru, Ed., University of Illinois Press, Urbana, Ill, USA, 1982.

[13] Salikoko S. Mufwene, "African-American English," in English in North America, J. Algeo et al., Ed., vol. 6 of The Cambridge History of the English Language, pp. 291-324, Cambridge University Press, 2001.

[14] David Crystal, The Language Revolution, Polity Press, Cambridge, Mass, USA, 2004.

[15] Gunnel Melchers and Philip Shaw, World Englishes: An Introduction, Oxford University Press, Oxford, UK, 2003.

[16] Rodney F. Moag, "The life cycle of non-native Englishes: a case study," in The Other Tongue: English Across Cultures, Braj B. Kachru, Ed., Pergamon Press, Oxford, UK, 1982.

[17] Rodney F. Moag, "The life cycle of non-native Englishes: a case study," in The Other Tongue: English Across Cultures, Braj B. Kachru, Ed., pp. 233-253, University of Illinois Press, Urbana, Ill, USA, 1992.

[18] Robert A. Hall, “The life cycle of pidgin languages," Lingua, vol. 11, no. C, pp. 151-156, 1962.

[19] Asmah Haji Omar, The Linguistic Scenery in Malaysia, Dewan Bahasa dan Pustaka, Kuala Lumpur, Malaysia, 1992.

[20] A Pennycook, The Cultural Politics of English as an International Language, Longman, London, UK, 1994.

[21] John Platt, Heidi Weber, and Lian Ho Mian, Singapore and Malaysia, vol. 4 of Varieties of English Around the World, John Benjamins, Amsterdam, The Netherlands, 1983.

[22] S. S. Mufwene, The Ecology of Language Evolution, Cambridge University Press, Cambridge, UK, 2001.

[23] Asmah Haji Omar, "From imperialism to Malaysianization: a discussion of the path taken by English towards becoming a Malaysian language," in English is an Asian Language: The Malaysian Context, Mohd Said Halimah and Keat Siew Ng, Eds., pp. 12-21, Persatuan Bahasa Moden Malaysia, Kuala Lumpur, Malaysia, 2000.

[24] Peter H. Lowenberg, "Variation in Malaysian English. The pragmatics of languages in contact," in English Around the World Sociolinguistic Perspectives, Jenny Chesture, Ed., Cambridge University Press, Cambridge, UK, 1991.

[25] Saran Kaur Gill, International Communication: English Language Challenges for Malaysia, Universiti Putra Malaysia, Serdang, Malaysia, 2002.

[26] Bjorn Jernudd, "Development of national language and management of English in East and Southeast Asia," in Language in the $21^{\text {st }}$ Century, Himphrey Tonkin and Timothy Regan, Eds., pp. 59-66, John Benjamins, Amsterdam, The Netherlands, 2003.

[27] Shanta Nair-Venugopal, Language Choice and Communication in Malaysian Business, Penerbit Universiti Kebangsaan Malaysia, Bangi, Malaysia, 2000.

[28] Elaine Morais, "Talking in English but thinking like a Malaysian: insights from a car assembly plant," in English Is An Asian Language: The Malaysian Context, Mohd Said Halimah and Keat Siew Ng, Eds., pp. 90-106, Persatuan Bahasa Moden Malaysia, Kuala Lumpur, Malaysia, 2000.

[29] Joanne Rajadurai, "The faces and facets of English in Malaysia," English Today, vol. 20, no. 4, pp. 54-58, 2004.

[30] Habibah Salleh, "Talking in English but thinking like a Malaysian: insights from a car assembly plant," in English Is An Asian Language: The Malaysian Context, Mohd Said Halimah and Keat Siew Ng, Eds., pp. 57-63, Persatuan Bahasa Moden Malaysia, Kuala Lumpur, Malaysia, 2000.

[31] Edgar W. Schneider, "Evolutionary patterns of New Englishes and the special case of Malaysian English," Asian Englishes, vol. 6, pp. 44-63, 2003.

[32] Asmah Haji Omar, "Post-imperial English in Malaysia," in Post-imperial English: Status Change in Former British and American Colonies, 1940-1990, Fishman et al., Ed., pp. 513555, Walter de Gruyter, 1996.

[33] Edgar W. Schneider, "Shakespeare in the coves and hollows? Towards a history of Southern English," in English in the Southern United States, Stephen J. Nagle and Sara L. Sanders, Eds., pp. 17-35, Cambridge University Press, Cambridge, UK, 2003.

[34] Mark Newbrook, "Malaysian English: status, norms, some grammatical and lexical features," in Englishes Around the World: Caribbean, Africa, Asia, Australasia, Schneider, Ed., vol. 2, pp. 229-256, John Benjamins, Amsterdam, The Netherlands, 1997.

[35] Loga Baskaran, "Malaysian English: phonology," in A Handbook of Varieties of English, Schneider et al., Ed., vol. 2, pp. 1034-1046, Mouton de Gruyter, 2004.

[36] Maya Khemlani David, "The language of Malaysian youthan exploratory study," in English is an Asian Language: The Malaysian Context, Mohd Said Halimah and Keat Siew Ng, Eds., pp. 64-72, Persatuan Bahasa Moden Malaysia, Kuala Lumpur, Malaysia, 2000.

[37] Mohd Said Halimah and Keat Siew Ng, Eds., English Is An Asian Language: The Malaysian Context, Persatuan Bahasa Moden Malaysia, Kuala Lumpur, Malaysia, 2000.

[38] Saran Kaur Gill, "Standard and linguistic realities of English in the Malaysian workplace," World Englishes, vol. 18, no. 2, pp. 215-231, 1999.

[39] Fadillah Merican, "Going native and staying strong: Malaysian fiction in English," in English Is An Asian Language: The Malaysian Context, Mohd Said Halimah and Keat Siew Ng, Eds., pp. 107-124, Persatuan Bahasa Moden Malaysia, Kuala Lumpur, Malaysia, 2000.

[40] Times-Chambers Essential English Dictionary, Federal Publications, Singapore, 1997.

[41] Macquarie University, Macquarie Junior Dictionary. World English-Asian Context, The Macquarie Library, New South Wales, Australia, 1999.

[42] Macquarie University, Grolier International Dictionary. World English in an Asian Context, The Macquarie Library, New South Wales, Australia, 2000.

[43] Ali Jassem Zaidan, Malaysian English: A Sociolinguistic and TESL/TEFL Perspective, Pustaka Antara, Kuala Lumpur, Malaysia, 1994. 
[44] John Augustin, "Regional Standards of English in Peninsular Malaysia," in New Englishes, John B. Pride, Ed., Newbury House Publishers, Rowley, Mass, USA, 1982.

[45] Loga Baskaran, "Indigenization of English (Malaysian English-Its Development \& Features)," in Proceedings of the Modern Language Association Conference on "The Language Situation in Malaysia?”, Kuala Lumpur, Malaysia, 1987.

[46] Irene Wong, Simplified Features in the Structure of Colloquial Malaysian English, University Press for SEAMO Regional Language Centre, Singapore, 1983.

[47] Malachi Edwin Vethamani, "What English do we teach?" in Proceedings of the Bengkel Pendidikan Cemerlang Guru-guru MRSM, Port Dickson, Malaysia, 1997.

[48] Irene Wong, "English in Malaysia," in English for Cross-cultural Communication, L. E. Smith, Ed., Macmillan, London, UK, 1981.

[49] Peter H. Lowenberg, English in the Malay Archipelago: Nativization and its functions in a Sociolinguistic Area, Bell \& Howell, Ann Arbor, Mich, USA, 1984.

[50] Peter H. Lowenberg, Language transfer and Levels of Meaning Potential in Malaysian English, Georgetown University Round Table on Languages and Linguistics, 1992.

[51] Elena G. Bokamba, "Are there syntactic constraints on codemixing?" World Englishes, vol. 8, no. 3, pp. 277-292, 1989.

[52] Williams J. Crewe, Singapore English and Standard English: Exercises in Awareness, Eastern Universities Press, Singapore, 1977.

[53] John Platt and Heidi Weber, English in Singapore and Malaysia, Oxford University Press, Kuala Lumpur, Malaysia, 1980.

[54] R. K. Tongue, The English in Singapore and Malaysia, Eastern University Press, Singapore, 1979.

[55] Loga Baskaran, "The Malaysian English Mosaic," English Today, vol. 10, no. 1, pp. 27-32, 1994.

[56] Irene Wong, "Native-speakers English for the third world today?" in New Englishes, John B. Pride, Ed., Newbury House Publisher, Rowley, Mass, USA, 1982.

[57] E. Morais, "Language choice in a Malaysian car-assembly plant," International Journal of the Sociology of Language, no. 130, pp. 89-105, 1998.

[58] Ling Poh Lean, "Malaysia most proficient in English in Asia," New Straits Times, April 2011.

[59] Anon., "Najib proud of Malaysia’s English proficiency," New Straits Times, April 2011: 4.

[60] Atan Hamidah, "300 US scholars to teach English," New Straits Times, June 2011.

[61] Kementerian Pelajaran Malaysia, "Benefits of MBMMBI: Capable of producing generation fluent in Bahasa Malaysia and English," New Straits Times, September 2011: 14. 

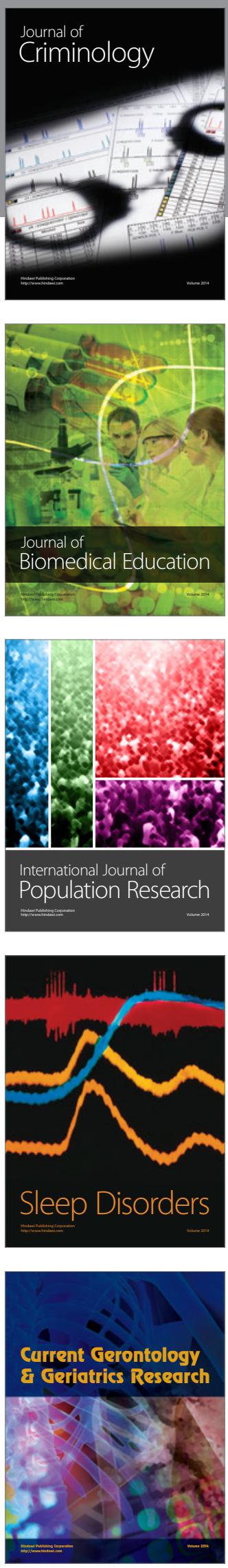
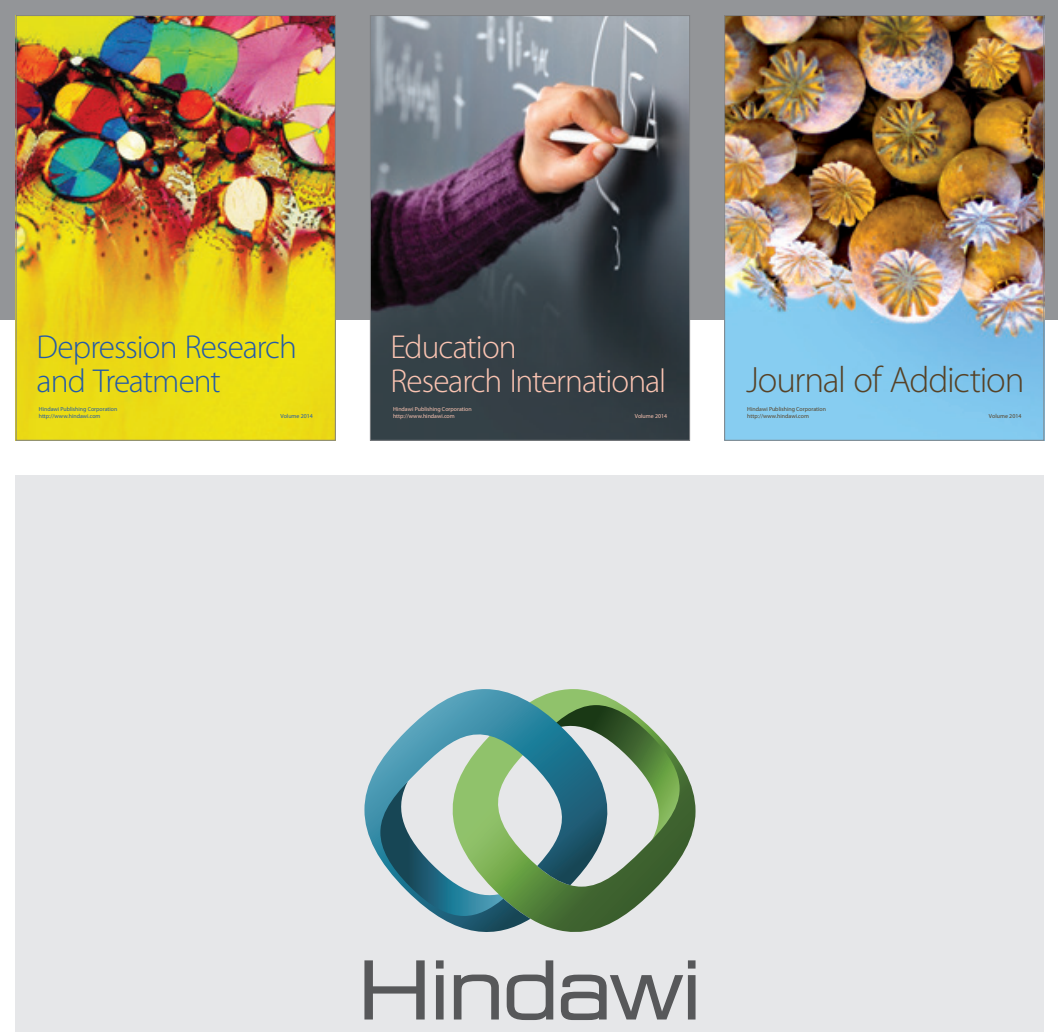

Submit your manuscripts at

http://www.hindawi.com

Child Development Research
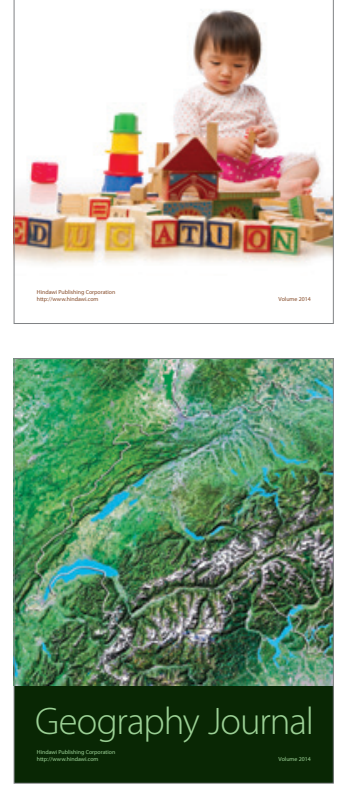

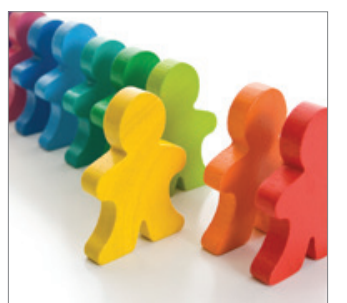

Autism

Research and Treatment
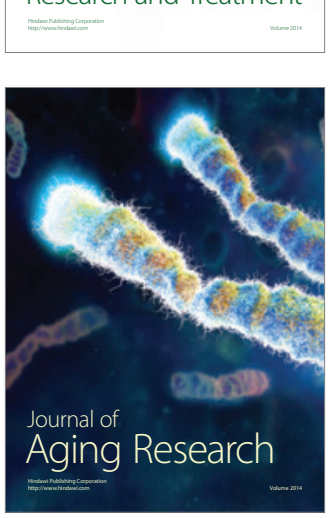
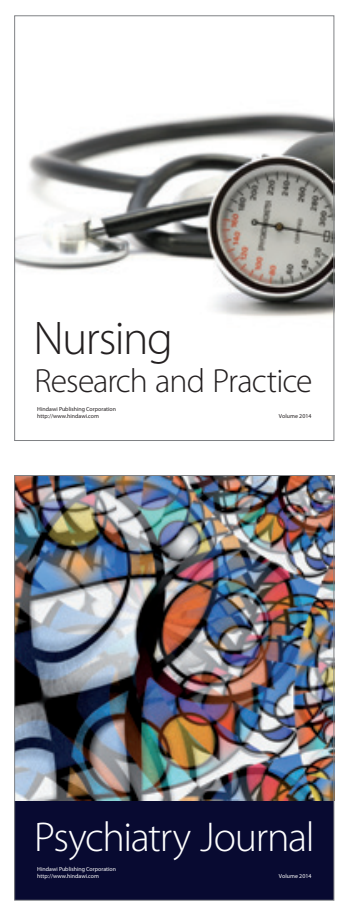
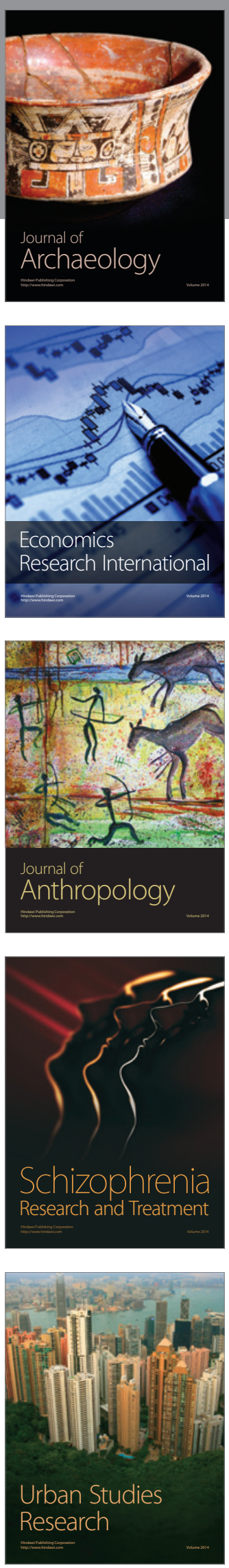